
\title{
R Research Soure \\ In Silico and in Vitro Development of a New Bipolar Radiofrequency Ablation Device for Renal Denervation
}

Noel Pérez ( $\nabla$ nperez21@outlook.com )

University of South Florida

Karl Muffly

University of South Florida

Stephen E. Saddow

University of South Florida

\section{Research Article}

Keywords: Basket catheter, high blood pressure, hypertension, radiofrequency ablation, renal denervation, resistant hypertension

Posted Date: April 12th, 2021

DOl: https://doi.org/10.21203/rs.3.rs-409680/v1

License: (a) (1) This work is licensed under a Creative Commons Attribution 4.0 International License. Read Full License 
1 Technical Advance

2 In silico and in vitro development of a new bipolar radiofrequency ablation device for

3 renal denervation

$4 \quad$ Noel Pérez ${ }^{1,3 *}$, Karl Muffly², Stephen E. Saddow ${ }^{1}$

5

$6{ }^{1}$ Department of Electrical Engineering and Department of Medical Engineering, University of

7 South Florida, Tampa, FL, USA

$8{ }^{2}$ Departments of Pathology \& Cell Biology and Surgery, University of South Florida, Tampa, $9 \mathrm{FL}, \mathrm{USA}$

$10{ }^{3}$ Oscor, Inc. Research and Development, Palm Harbor, Florida, USA

12 Running head: A new RFA device for renal denervation

14 *Correspondence to: Noel Pérez, Oscor, Inc. Research and Development, Palm Harbor, 15 Florida, USA and Department of Electrical Engineering, University of South Florida, Tampa, 16 FL, USA. Email: nperez21@outlook.com

18 Abstract

19 Background: Renal denervation with radiofrequency ablation has become an accepted 20 treatment for drug-resistant hypertension. However, there is a continuing need to develop 21 new catheters for high-accuracy, targeted ablation. We, therefore, developed a

22 radiofrequency ablation device with a basket catheter and bipolar electrodes for controlled, 23 targeted ablation through Joule heating induction between $60^{\circ} \mathrm{C}$ and $100^{\circ} \mathrm{C}$. 
Methods: Finite element modeling was used to determine the optimum catheter design to deliver a minimum ablation zone of $4 \mathrm{~mm}(\mathrm{~W}) \times 10 \mathrm{~mm}(\mathrm{~L}) \times 4 \mathrm{~mm}(\mathrm{H})$ within 60 seconds with a $500 \mathrm{kHz}, 60 \mathrm{Vp}-\mathrm{p}$ signal, and $0.9 \mathrm{~W}$ maximum. The computational model was

27 validated using in vitro phantom tissue impregnated with a color-changing thermochromic pigment.

Results: The in vitro ablation zone closely matched the size and shape of the simulated area. The new electrode design directs the current density towards the artery walls and tissue, reducing unwanted blood temperature increases by focusing energy on the ablation zone. In contrast, the basket catheter design does not block renal flow during renal denervation.

Conclusions: This computational model of radiofrequency ablation can be used to estimate renal artery ablation zones for highly targeted renal denervation in patients with resistant hypertension. Furthermore, this innovative catheter has short ablation times and the lowest power requirement of existing designs to perform the ablation.

Keywords: Basket catheter, high blood pressure, hypertension, radiofrequency ablation, renal denervation, resistant hypertension

\section{Background}

Hypertension is extremely common and, if inadequately treated, significantly increases the risk of heart disease, stroke, and death. A 12-13 $\mathrm{mmHg}$ reduction in systolic blood pressure in hypertensive patients equates to at least a $21 \%$ reduction in stroke, coronary heart disease, and death from cardiovascular disease [1]. In 2020, the American Heart Association (AHA) reported that $31.9 \%$ of the American population ( 75 million people) have hypertension, resulting in $\sim 90,000$ deaths from hypertension annually and an annual healthcare expenditure of $\$ 55.9$ billion [2]. 

hypertension resistant to three or more medications resulting in a blood pressure higher than a target of $\geq 130 / 80 \mathrm{mmHg}$ or a blood pressure $<130 / 80 \mathrm{mmHg}$ in a patient taking $\geq$ four antihypertensive drugs. $\mathrm{RH}$ affects $12-15 \%$ of patients treated for hypertension and remains a clinical management challenge [3]. nervous system. As early as 1889 , experiments with dogs showed that stimulation of renal or splanchnic nerves caused changes in blood pressure [4]. In 1925, Adson performed surgical sympathectomy (disconnection of the sympathetic nerves at the trunk) to treat hypertension [5]. For the subsequent two decades, surgical sympathectomy (thoracolumbar splanchnicectomy) became the procedure of choice for patients with HT who did not respond to diet or the then limited available pharmacological therapy [6]. Indeed, between 1938 and 1947, approximately 2,400 patients with hypertension were treated by surgical sympathectomy [7]. Although blood pressure reductions after the operation were often significant, patients were seriously affected by intolerable post-operative postural hypotension [8]. When the first effective antihypertensive drugs (diuretics) became available in the mid-1950s, pharmacological therapy became the standard of care for patients with hypertension [9]. Since stimulation of the renal nerves raises blood pressure through vasoconstriction

67 and volume and sodium retention [10-12], ablating renal nerve activity (renal denervation; RD) effectively lowers blood pressure [13]. The highest density of renal sympathetic nerves is within 12 to $15 \mathrm{~mm}$ of the abdominal aorta and within $4 \mathrm{~mm}$ radially from the renal artery inner lumen [14]. RD's goal is to "open circuit" the efferent and afferent renal sympathetic nerves between the kidneys and the central nervous system to reduce blood pressure. 
72 Indeed, the first bilateral RDs for hypertension were performed in 1934 and 1935, establishing the procedure's safety with no adverse effect on renal function $[15,16]$. The last ten years have seen a surge in the minimally-invasive, catheter-based delivery of radiofrequency, chemicals, or ultrasound to achieve RD in hypertensive patients [13]. Although early trial results from the SYMPLICITY HTN-3 trial of RD were disappointing, with

77 the primary efficacy endpoint not met [17], subsequent trials using next-generation multielectrode radiofrequency (RF) and ultrasound renal nerve ablation systems have shown consistent blood-pressure-lowering effects of $\operatorname{RD}[11,12]$. Furthermore, the SYMPLICITY HTN-3 trial results led to the improvement and redesign of the ablation catheter from a single point unipolar ablation electrode to a four-quadrant unipolar device. In addition to the RF electrode design or means of ablation, recent data suggest that the efficacy of RD depends on the successful ablation of renal fibers associated with arterial branches and polar arteries [18], necessitating the development of effective, smalldiameter catheters. in the USA except for investigational purposes [19]. Here, we report in vitro RF ablation using bipolar electrodes on thermochromic phantom tissue to validate a targeted RD computational model for human use. Our new catheter design does not block renal blood flow, does not require cooling, and has low power consumption due to the bipolar electrode

91 design.

\section{Methods}


The finite-element method (FEM) has previously been used to model RF tumor or cardiac ablation [20-22]. Here we also used FEM to solve electromagnetic equations coupled with bioheat equations for bipolar electrodes in contact with tissue design to deliver a minimum ablation zone of $4 \mathrm{~mm}(\mathrm{~W}) \times 10 \mathrm{~mm}(\mathrm{~L}) \times 4 \mathrm{~mm}(\mathrm{H})$ within 60 seconds with a $500 \mathrm{kHz}, 60 \mathrm{Vp}$ $\mathrm{p}$ signal and $0.9 \mathrm{~W}$ maximum.

COMSOL version 5.5 (COMSOL, Stockholm, Sweden) was used to generate geometric models, assign material properties and boundary conditions, define infinite element domains, generate meshes, and perform the coupled electromagnetic heating calculations. A coupled analysis was required since the electrical properties of tissue change with temperature and, therefore, the electric field profile must be recalculated at each time step. All analyses were performed on a PC equipped with an Intel ${ }^{\circledR}$ Core $^{\mathrm{TM}}$ i7-9700 CPU @ 3GHz, 64 GB of memory, and Windows 10 Home OS.

\section{Model geometry}

We developed a 3D FEM model geometry of bipolar cylindrical electrodes inside a renal artery surrounded by connective tissue (Figure 1A). The renal artery internal diameter was $4.1 \mathrm{~mm} \mathrm{[14],} \mathrm{the} \mathrm{wall} \mathrm{(tunica} \mathrm{intima} \mathrm{and} \mathrm{media)} \mathrm{thickness} \mathrm{was} 0.5 \mathrm{~mm}$ [23], and the surrounding connective tissue was modeled to a radius of $10 \mathrm{~mm}$. An infinite element domain was defined around the geometric model for approximating an infinitely large domain (Figure 1A). The electrode dimensions were $0.61 \mathrm{~mm}$ outside diameter, $0.1 \mathrm{~mm}$ thickness, and $3 \mathrm{~mm}$ long assembled over a Pellethane ${ }^{\circledR}$ tube. The electrodes were designed to be in contact with the renal artery's inner wall through an exposed window of $1 \mathrm{~mm} \times 2.5$ $\mathrm{mm}$, as shown in Figure 1B (patent pending). 


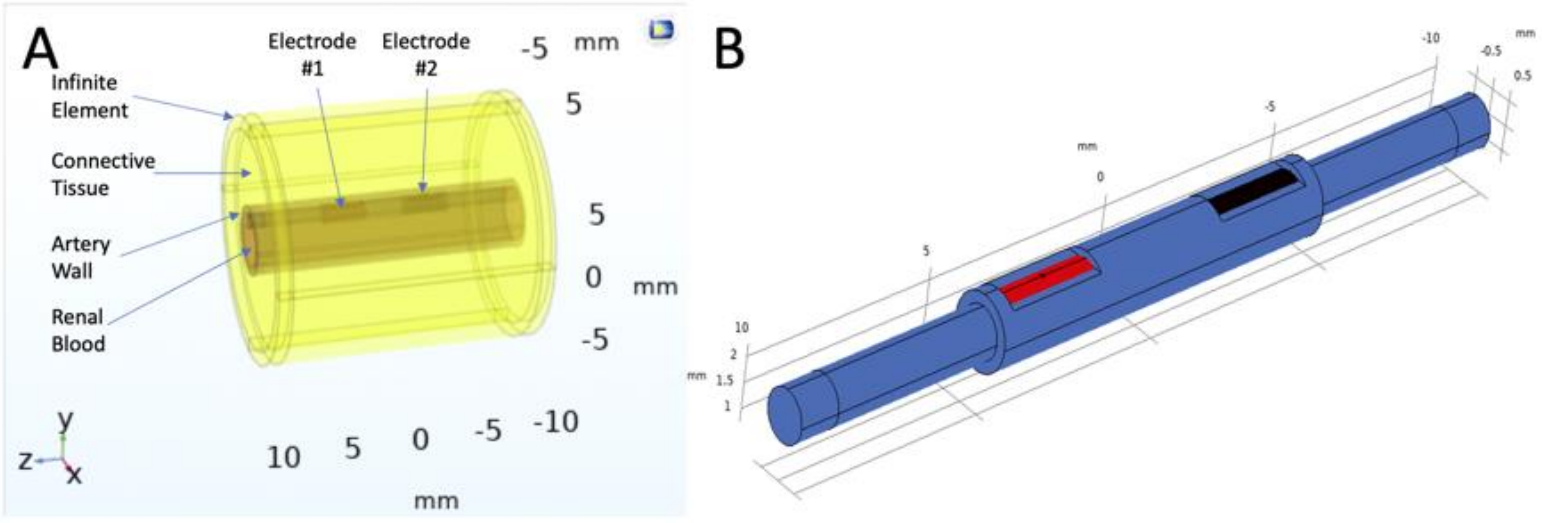

120 Figure 1. (A) 3D model geometry for FEM analysis of the bipolar electrodes in contact with

121 phantom tissue to mimic placement inside the renal artery. Electrode dimensions: diameter

$1220.61 \mathrm{~mm}$, length $3 \mathrm{~mm}$ with a $1.5 \mathrm{~mm}$ separation. (B) Innovative bipolar electrode design

123 (patent pending) to focus current density towards the artery wall and surrounding tissue.

124 Electrodes (red and black) dimensions as per (A).

125

126 Electrical and thermal properties

127 Table 1 shows the material properties at $500 \mathrm{kHz}$ used in the computational model to

128 describe the blood, artery wall, connective tissue, thermoplastic catheter material (Pebax $\left.{ }^{\circledR}\right)$,

129 and electrode components.

130

131 Table 1. Electrical and thermal properties at $500 \mathrm{kHz}$ for components in the FEM model.

132

\begin{tabular}{cccccc}
\hline \hline Component & $\begin{array}{c}\text { Relative } \\
\text { Permittivity } \\
\left(\varepsilon_{\mathrm{r}}\right)\end{array}$ & $\begin{array}{c}\text { Electrical } \\
\text { Conductivity } \\
\sigma(\mathrm{S} / \mathrm{m})\end{array}$ & $\begin{array}{c}\text { Density } \\
\left(\mathrm{kg} / \mathrm{m}^{3}\right)\end{array}$ & $\begin{array}{c}\text { Heat Capacity at } \\
\text { Constant Pressure } \\
\mathrm{J} /\left(\mathrm{kg}-{ }^{\circ} \mathrm{C}\right)\end{array}$ & $\begin{array}{c}\text { Thermal Conductivity } \\
\mathrm{W} /\left(\mathrm{m}-{ }^{\circ} \mathrm{C}\right)\end{array}$ \\
\hline Blood $^{\mathrm{a}}$ & 4,190 & 0.748 & 1,050 & 3,617 & 0.52 \\
Artery Wall $^{\mathrm{a}}$ & 312 & 0.324 & 1,102 & 3,306 & 0.46 \\
Connective Tissue $^{\mathrm{a}}$ & 201 & 0.391 & 1,027 & 2,372 & 0.39 \\
Pebax $^{\circledR} 7233^{\mathrm{b}}$ & 4 & $1.25 \mathrm{E}-12$ & 1,010 & 1,700 & 0.26 \\
Electrodes (PtIr 90/10) $^{\mathrm{c}, \mathrm{d}}$ & 1 & $1.00 \mathrm{E}+09$ & 7,950 & 502 & 14
\end{tabular}


139 (artery walls and connective tissue) [24] and, during RF ablation, the temperature of tissues

140 increases. The changes to the electrical conductivity in tissues included in the model were

141 described using:

$$
\left.\sigma(T)=\sigma_{\mathrm{o}}\left[1+k_{1} \Delta T\right)\right]
$$

143 where $\sigma$ is the initial electrical conductivity at the reference temperature, $k^{1}$ is the

144 temperature coefficient, and $\Delta T\left[{ }^{\circ} \mathrm{C}\right]$ is the temperature difference from the initial reference 145 temperature. We set $k^{1}=2.05 \% /{ }^{\circ} \mathrm{C}$, and the linear electrical conductivity in the model was 146 determined by

$$
\sigma(T)=0.324[1+0.0205 \Delta T)]
$$

148 For the artery wall and connective tissue, the equation was

$$
\sigma(T)=0.391[1+0.0205 \Delta T)]
$$

Both equations are bounded within the experimental data of $30-80^{\circ} \mathrm{C}[25]$.

Multi-physics computation

\section{Electric field}

154 When electric fields are applied to tissue, the temperature in the zone between the bipolar 155 electrodes increases due to Joule heating through tissue conduction and dielectric loss. For 156 the tissues in the model at $500 \mathrm{kHz}$, dielectric losses are negligible, so only the resistive loss

157 (i.e., Joule heating) was considered in this simulation [26]. The electric field E (V/m) profile was calculated from the negative gradient of the voltage using the equation

$$
\mathbf{E}=-\nabla \mathbf{V}
$$

160 where $\nabla$ is the del operator that turns the scalar voltage $\mathbf{V}(\mathrm{V})$ to a vector field. Then, 161 current density $\mathrm{J}\left(\mathrm{A} / \mathrm{m}^{2}\right)$ was computed from 


$$
J=\frac{\mathbf{E}}{\rho e}
$$

163 where $\rho e$ is the electrical resistivity of the material $(\Omega-m)$. Then, the average power dissipated in the tissue between the electrodes was determined by

$$
P_{\mathrm{av}}=\frac{1}{2} \mathfrak{R}\left(\boldsymbol{J}^{*} \cdot \boldsymbol{E}\right)
$$

where $\mathfrak{R}$ is the real part from the vector dot product of conjugate $\boldsymbol{J}$ and $\boldsymbol{E}$.

\section{Bioheat equation}

Penne's bioheat equation describes the temperature distribution increase surrounding the

bipolar electrodes during the Joule heating process and incorporates the convective heat transfer from blood perfusion within the tissue

$$
\rho C_{\mathrm{p}} \frac{\partial T}{\partial t}-\nabla \cdot k \nabla T=\frac{1}{2} \mathfrak{R}\left(\boldsymbol{J}^{*} \cdot \boldsymbol{E}\right)+\rho_{\mathrm{b}} C_{\mathrm{p}, \mathrm{b}} \omega_{\mathrm{b}}\left(T_{\mathrm{b}}-T\right)+Q_{\text {met }}(7)
$$

173 where $\rho$ is the tissue density $\left(\mathrm{kg} / \mathrm{m}^{3}\right), C_{p}$ is the tissue-specific heat $(\mathrm{J} / \mathrm{kg} \cdot \mathrm{K})$, and $k$ is the

174 tissue thermal conductivity $(\mathrm{W} / \mathrm{m}-\mathrm{K})$ of the components in the model. $\mathrm{T}_{\mathrm{b}}$ is the blood

175 temperature (assumed to be $37^{\circ} \mathrm{C}$ ), $\rho_{\mathrm{b}}$ is blood density $\left(\mathrm{kg} / \mathrm{m}^{3}\right), C_{p, b}$ the specific heat of the

$176 \operatorname{blood}(\mathrm{J} / \mathrm{kg} \cdot \mathrm{K})$, and $\omega_{b}$ is the blood perfusion $(1 / \mathrm{s}) . Q_{m e t}$ is the energy generated by

177 metabolic processes $\left(\mathrm{W} / \mathrm{m}^{3}\right)$ and is negligible for the renal artery model. The blood temperature in large surrounding vessels has minimal impact on the thermal field between the bipolar electrodes due to their distance from the renal artery and was therefore not included in the model.

\section{Boundary conditions}

183 Artery walls and surrounding tissue with Dirichlet boundary conditions: temp = normal body temperature $\left(37^{\circ} \mathrm{C}\right)$ and voltage $=0 \mathrm{~V}$. 
Ablated tissue

187 To determine the ablation zone (i.e., where cell death occurs), the Thermal Damage transformation model was included in the COMSOL model with a temperature threshold.

The isothermal surfaces were plotted using the following parameters to determine the ablation zone: damage temperature $60^{\circ} \mathrm{C}$, damage time $1 \mathrm{~s}$, necrosis temperature $90^{\circ} \mathrm{C}$, and enthalpy change $0 \mathrm{~J} / \mathrm{kg}$.

In vitro experiments

We prepared a thermochromic tissue phantom (TCP) for direct visualization of ablation and comparison with the simulated isothermal ablation zones. The TCP mimicked the tissue's electrical properties and was prepared using polyacrylamide gel with a thermochromic ink additive that permanently changes color from white to magenta when heated over $60^{\circ} \mathrm{C}$. The TCP was formulated as described by Mikhail et al. [27] and contained: deionized water $76.1(\mathrm{v} / \mathrm{v}), 40 \%$ acrylamide/bis-acrylamide $17.5(\mathrm{v} / \mathrm{v})$, magenta $\mathrm{MB} 60^{\circ} \mathrm{C}$ concentrate $5.0(\mathrm{v} / \mathrm{v})$ sodium chloride ( $\mathrm{NaCl}) 0.9(\mathrm{w} / \mathrm{v})$, ammonium persulfate (APS) $0.14(\mathrm{w} / \mathrm{v})$, and $\mathrm{N}, \mathrm{N}, \mathrm{N}^{\prime}, \mathrm{N}^{\prime}$ tetramethylethylenediamine (TEMED) $0.14(\mathrm{v} / \mathrm{v})$. The electrical conductivity was adjusted to match the connective tissue since this is the most relevant parameter for the thermal Joule heating effect.

The TCP was ablated with a bipolar electrode connected to a waveform generator and linear amplifier, as shown in Figure 2. The exposed surface of the electrodes was in contact with the TCP and impregnated with saline solution, which mimics the conductivity of blood. An ablation signal of $3.0 \mathrm{~V}_{\mathrm{p}-\mathrm{p}}$ and $500 \mathrm{kHz}$ was generated with an Agilent 33220A waveform generator (Agilent, Santa Clara, CA, USA) and amplified to $60 \mathrm{~V}_{\mathrm{p}-\mathrm{p}}$ with a 
211 Multimeter (Fortive, Everett, WA, USA) were connected to monitor and confirm that the

212 appropriate ablation signal was applied to the TCP through the electrodes (not shown in

213 Figure 2 for simplification).

214

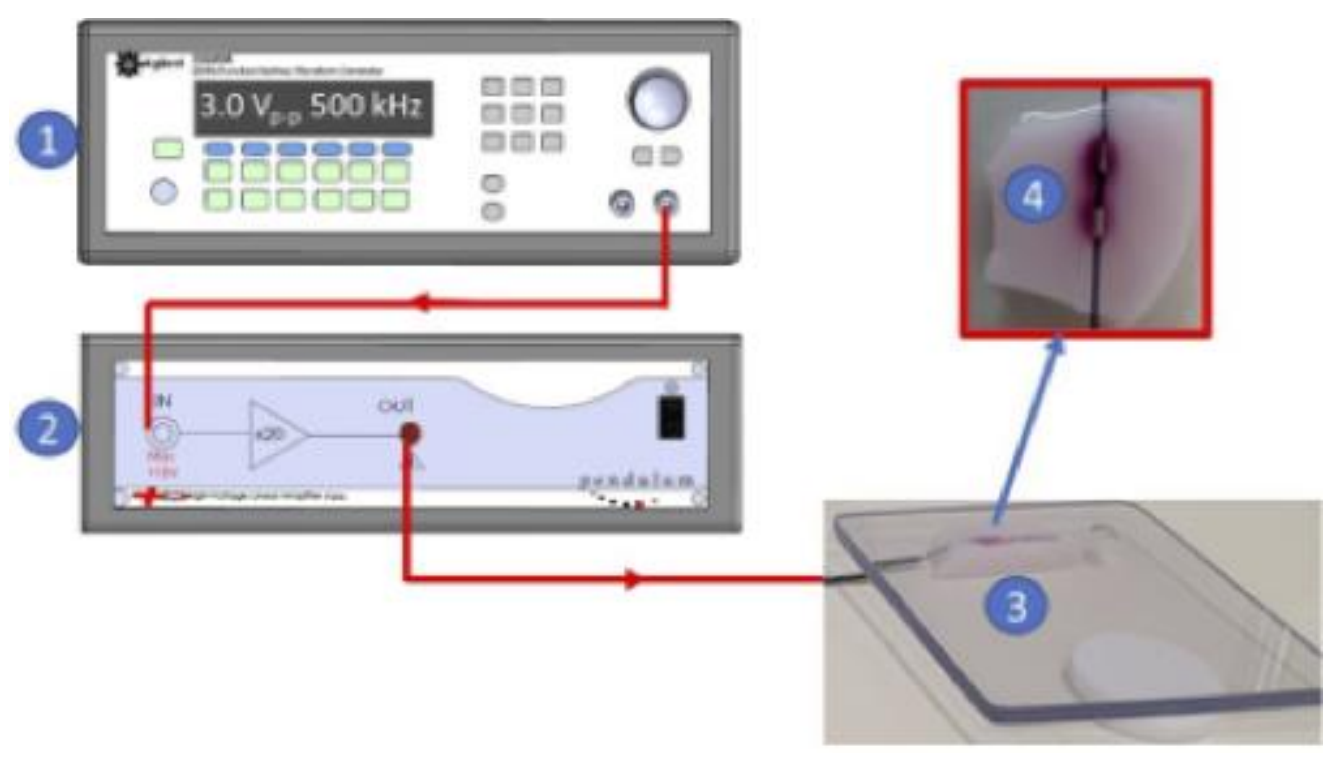

216 Figure 2. Thermochromic tissue phantom (TCP) ablation experimental setup. 1) Signal

217 generator ( $3 \mathrm{Vp}-\mathrm{p}, 500 \mathrm{kHz}$ ) was amplified by 2) 20 gain linear power amplifier (60 Vp-p, 500 $\mathrm{kHz}$ ) and 3) applied to TCP with a bipolar electrode and an insulating plate to maintain its position. 4) Top view of the TCP ablated by the bipolar electrodes in 60 seconds.

Oscilloscope and precision meter not shown for clarity.

\section{Results}

223 RF ablation catheter design

224 The bipolar electrode design in this study (Figure 1) can be assembled in a 6 Fr catheter with 225 four splines carrying either 2 or 4 electrodes per spline. Each spline is made of thermoplastic 
$226\left(\right.$ Pebax $\left.^{\circledR}\right)$ extrusions with their inner lumen containing a pre-shaped nickel-titanium (Nitinol)

227 and electrical wires (Figure 3). The Nitinol provides a collapsible basket to be delivered

228 through femoral access to the renal artery. It expands to the pre-shaped form creating firm

229 connectivity between the electrodes and the artery inner walls. Each bipolar electrode can

230 be independently selected for ablation of each quadrant in contact with the splines inside

231 the artery (patent pending).

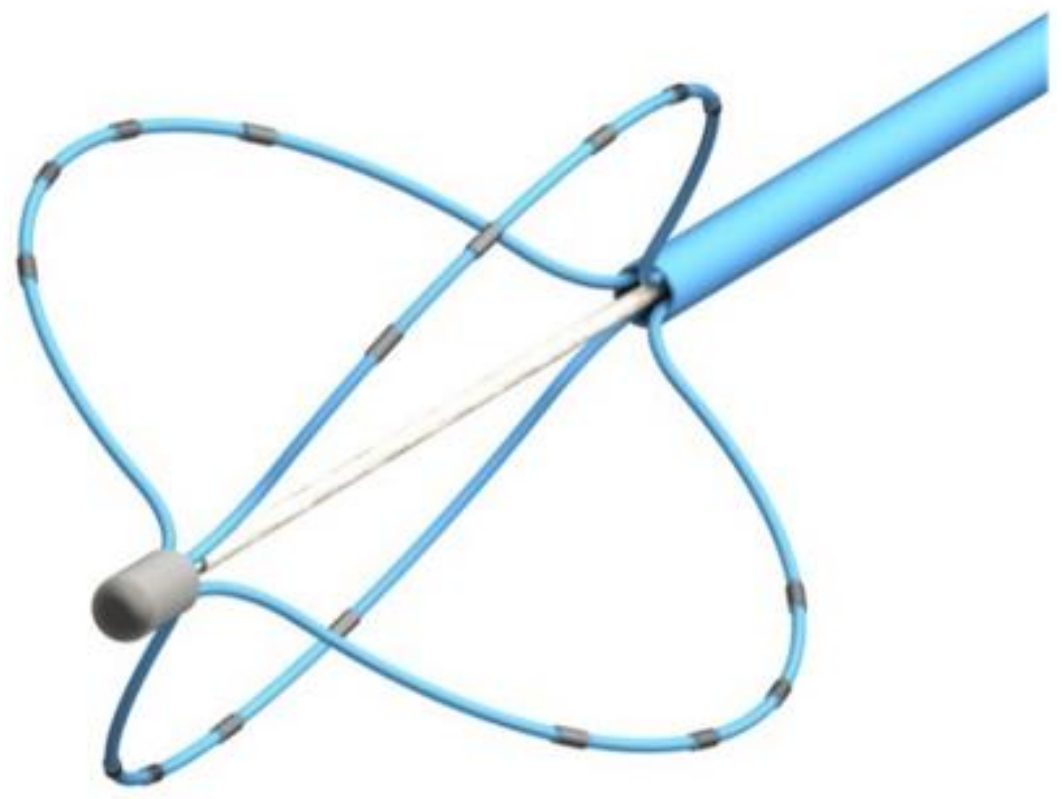

233

234 Figure 3. Graphical model of the basket catheter with four splines and four electrodes per splines. Note: two splines have a fifth, non-active radio-opaque electrode for position orientation during fluoroscopy.

In silico and in vitro comparisons

239 The isothermal plot from the computer model (Figure 4A) predicted the tissue volume that reached an ablation temperature of $\geq 60^{\circ} \mathrm{C}$ after 60 seconds of ablation due to the induced 
Joule heating. The ablated area consisted of two elongated lobes with an approximate

242 maximum dimension of $4 \mathrm{~mm} \times 10 \mathrm{~mm} \times 4 \mathrm{~mm}$ (length $\times$ width $\times$ height).

244 plot from the computer model (Figure 4A) and is shown in Figure 4C. Note the excellent

245 correlation between simulated and experimentally defined areas (4 mm x $10 \mathrm{~mm} \times 4 \mathrm{~mm}$ vs.

$2463 \mathrm{~mm} \times 8.5 \mathrm{~mm} \times 3.5 \mathrm{~mm}$ ), indicating that the computer model accurately predicted the RF

247 ablation zone in vitro.

248

A

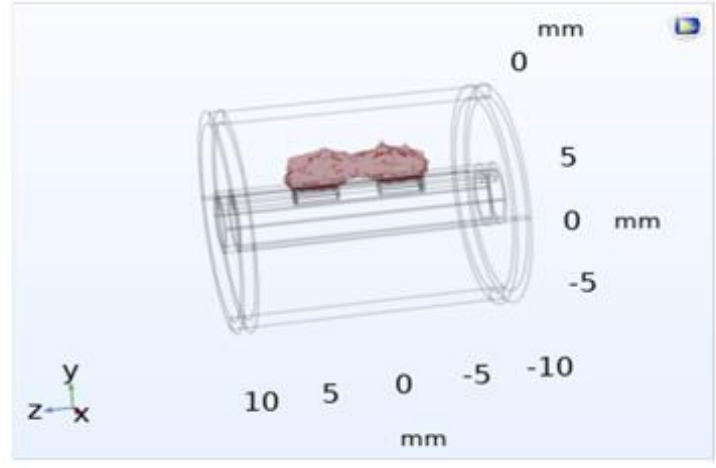

C
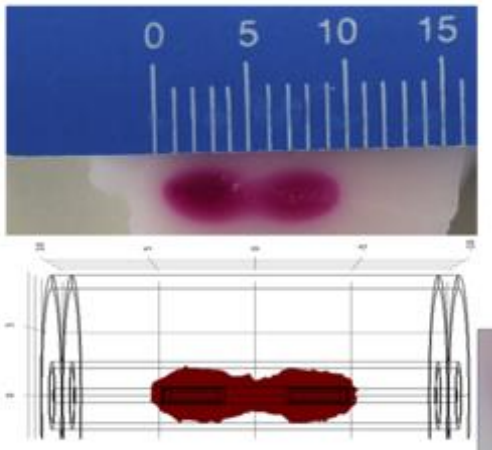

B
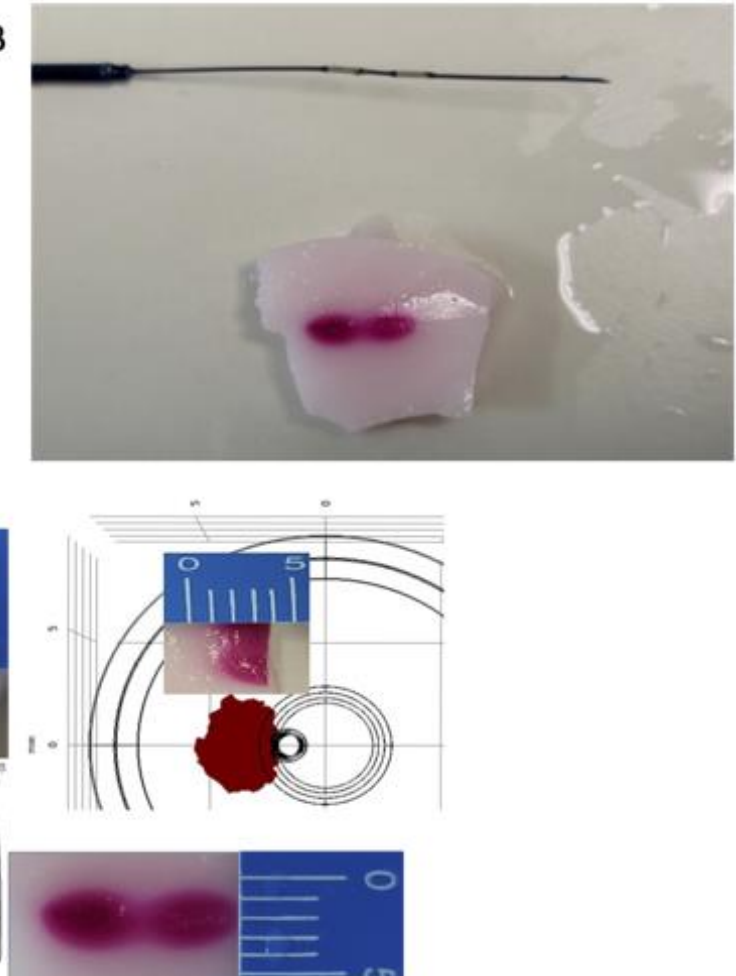

Figure 4. (A) Computer simulation of the isothermal ablation zone for a $500 \mathrm{kHz}$ input signal with an amplitude of $60 \mathrm{Vp}-\mathrm{p}$ at 60 seconds of ablation. The computer model predicted an ablation zone of $4 \mathrm{~mm} \times 10 \mathrm{~mm} \times 4 \mathrm{~mm}$ (length $\mathrm{x}$ width $\mathrm{x}$ height) over the bipolar electrodes. (B) Thermochromic tissue phantom (TCP) after an ablation signal $(500 \mathrm{kHz}, 60$ Vp-p) was applied for 60 seconds. The dark pink color change corresponds to the area 
where the temperature exceeded $60^{\circ} \mathrm{C}$. Note the similarities with the computer model in

257 (A). (C) Ablation zone comparison between computer model (A) and TCP tissue experiment

258 (B). The ablation zone was $3 \mathrm{~mm} \times 8.5 \mathrm{~mm} \times 3.5 \mathrm{~mm}$. Note the very close correlation

259 between the experimental and simulated ablation volumes.

260

261

Discussion

262

Resistant hypertension remains common and a clinical management challenge [1].

After initially disappointing clinical trial results, the technique's refinement has now resulted

in the inconsistent demonstration of RD efficacy for patients with treatment-resistant

265

hypertension [11, 12]. However, the Food and Drug Administration (FDA) has not approved

any device for RD except for investigational purposes, despite the many ongoing clinical

267

trials for RD and suggesting a need for further catheter refinement.

Several RF ablation catheter devices with the CE mark are authorized for use in the

European Union (EU) (Table 2). All are single electrode devices except for the Vessix ${ }^{\mathrm{TM}}$

(Boston Scientific, Marlborough, MA), incorporating a balloon with bipolar electrodes [19].

271

This has the consequent disadvantage that once inflated, the balloon blocks renal blood

272 flow during ablation. Our electrode design based on a basket catheter does not require a

273 balloon, so it has the advantage of no renal blockage during ablation. Furthermore, there is

274 no need for cooling, and the catheter has short ablation times and the lowest power

275 requirement of existing designs to perform the ablation.

276

277 Table 2. A comparison of CE-marked renal denervation catheters and our catheter. Adapted 278 from [19]. 


\begin{tabular}{|c|c|c|c|c|c|c|c|c|c|}
\hline Catheter & Energy & Configuration & Electrode & Balloon & Cooling & Delivery & $\begin{array}{l}\text { Ablation } \\
\text { time } \\
\text { (s/artery) }\end{array}$ & $\begin{array}{l}\text { Max. } \\
\text { power } \\
\text { (W) }\end{array}$ & $\begin{array}{l}\text { Vascular } \\
\text { access } \\
\text { (Fr) }\end{array}$ \\
\hline $\begin{array}{l}\text { Simplicity }^{\mathrm{TM}} \\
\text { (Medtronic) }\end{array}$ & RF & Unipolar & Single & No & Blood & $\begin{array}{l}\text { Deflectable } \\
\text { tip }\end{array}$ & 540 & 8 & 6 \\
\hline $\begin{array}{l}\text { Spyral }^{\mathrm{TM}} \\
\text { (Medtronic) }\end{array}$ & $\mathrm{RF}$ & Unipolar & Multiple & No & Blood & Monorail & 60 & 8 & 6 \\
\hline $\begin{array}{l}\text { Vessix }^{T M} \text { (Boston } \\
\text { Scientific) }\end{array}$ & $\mathrm{RF}$ & Bipolar & Multiple & Yes & None & $\begin{array}{l}\text { Over-the- } \\
\text { wire }\end{array}$ & 30 & 1 & 8 \\
\hline $\begin{array}{l}\text { EnligHTN }{ }^{\mathrm{TM}} \text { (St } \\
\text { Jude) }\end{array}$ & $\mathrm{RF}$ & Unipolar & Multiple & No & Blood & $\begin{array}{l}\text { Delectable } \\
\text { tip }\end{array}$ & 90 & 6 & 8 \\
\hline Iberis $^{\mathrm{TM}-}$ (Terumo) & $\mathrm{RF}$ & Unipolar & Single & No & Blood & $\begin{array}{l}\text { Delectable } \\
\text { tip }\end{array}$ & 540 & 8 & 4 \\
\hline $\begin{array}{l}\text { Paradise }^{\mathrm{TM}} \\
\text { (Recor) }\end{array}$ & US & Unipolar & Single & Yes & $\begin{array}{l}\text { Close } \\
\text { irrigated }\end{array}$ & $\begin{array}{l}\text { Over-the- } \\
\text { wire }\end{array}$ & $50-150$ & 30 & 6 \\
\hline Our design & $\mathbf{R F}$ & Bipolar & $\begin{array}{l}\text { Multiple } \\
\text { (8 or } 16)\end{array}$ & No & $\begin{array}{l}\text { Not } \\
\text { required }\end{array}$ & $\begin{array}{l}\text { Guided } \\
\text { sheet }\end{array}$ & 60 & 0.9 & 6 \\
\hline
\end{tabular}

281 Symplicity HT1 ${ }^{\mathrm{TM}}$, Medtronic, Santa Clara, CA, USA) to multi-electrode unipolar systems

282 (Spyral $\left.{ }^{\mathrm{TM}}\right) \cdot[28]$ Here we designed a bipolar electrode for RF ablation with the electrode

283 design, dimensions, geometry, and ablation area simulated and optimized via FEM in silico.

284 The simulation included the surrounding artery and connective tissue's electrical properties

285 to predict the ablation zone dimensions to achieve renal nerve ablation. A TCP was used to compare the in vitro ablation zone with simulations. While the TCP starts changing color at $60^{\circ} \mathrm{C}$, there is considerable variability to determine the exact location where the TCP starts to display temperature color transition. Nevertheless, the TCP allows visual and quantitative comparison of the geometry, shape, and form of ablation, which in this case very closely matched the computational simulation. Therefore, this model will be helpful for further 
optimizing catheter design for accurate renal nerve ablation in animal models in vivo to

292

294

295

296

297

298

299

300

301

302

303

304

305

306

307

\section{Abbreviations} and human trials.

\section{Conclusions} pave the way for clinical validation.

This computational model of RF ablation can be used to estimate ablation zones in the renal artery for RD in patients with hypertension. The model provides an efficient iterative platform to design and refine RF ablation electrodes for targeted ablation geometries and dimensions. The model can be extended to other anatomical landmarks to predict the RF ablation pattern in the targeted zone. This model is complemented by the TCP to provide a relatively simple and cost-effective in vitro medium for quick feedback to the computational model from RF ablation experiments, allowing short iteration times during catheter development compared to traditional, costly, and time-consuming animal

Our bipolar RF ablation electrode deserves further study and development as a potential RD device. The bipolar configuration and innovative electrode design ensure that the current density is focused on the target tissue, reducing the energy transferred to renal blood, reducing the need for cooling. Furthermore, the electrode window can be modified in shape and dimensions based on the intended location and geometry desired for ablation. This model and TCP can be used to investigate other ablation applications, e.g., tumor ablation, to design an electrode for the specifically intended zone. Further ex vivo and in vivo studies are warranted to further validate this new bipolar catheter system.

\section{AHA, American Heart Association}


315 FDA, Food and Drug Administration

316 FEM, finite element modeling

$317 \mathrm{RD}$, renal denervation

$318 \mathrm{RF}$, radiofrequency

$319 \mathrm{RH}$, resistant hypertension

320 TCP, thermochromic tissue phantom

$321 \mathrm{HT}$, Hypertension

322

323 Ethics approval and consent to participate

324 Not applicable

325 Consent for publication

326 Not applicable

327 Availability of data and materials

328 All data generated or analyzed during this study are included in this published article

329 Competing interests

330 This work was funded in part by Eng. Thomas Osypka, CEO and President of Oscor, Inc.,

331 Palm Harbor, Florida, USA

332 Funding

333 This work was funded in part by Eng. Thomas Osypka, CEO and President of Oscor, Inc.,

334 Palm Harbor, Florida, USA

335 Authors' contributions

336 N.P. conducted the experiments and wrote the manuscript; K.M. and S.E.S. advised on the

337 experiments' design. All authors reviewed the manuscript. 
340 1. State heart disease and stroke prevention program addresses high blood pressure [https://www.cdc.gov/dhdsp/data_statistics/fact sheets/fs state hbp.htm]

342 2. Virani SS, Alonso A, Benjamin EJ, Bittencourt MS, Callaway CW, Carson AP, Chamberlain AM, Chang AR, Cheng S, Delling FN et al: Heart Disease and Stroke Statistics-2020 Update: A Report From the American Heart Association. Circulation 2020, 141(9):e139-e596.

3. Vongpatanasin W: Resistant hypertension: a review of diagnosis and management. JAMA 2014, 311(21):2216-2224.

4. Bradford JR: The Innervation of the Renal Blood Vessels. J Physiol 1889, 10(5):358432318.

350

5. Adson A, Craig W, Brown G: Surgery in its relation to hypertension. Surg Gynecol

6. Papademetriou V, Rashidi AA, Tsioufis C, Doumas M: Renal nerve ablation for resistant hypertension: how did we get here, present status, and future directions. Circulation 2014, 129(13):1440-1451.

7. Smithwick RH, Thompson JE: Splanchnicectomy for essential hypertension; results in 1,266 cases. J Am Med Assoc 1953, 152(16):1501-1504.

8. Peet MM, Woods WW, Braden S: The surgical treatment of hypertension: results in 350 consecutive cases treated by bilateral supradiaphragmatic splanchnicectomy and lower dorsal sympathetic ganglionectomy. J Am Med Assoc 1940, 115(22):18751885. 
9. Freis ED, Wanko A, Wilson IM, Parrish AE: Treatment of essential hypertension with chlorothiazide (Diuril): its use alone and combined with other antihypertensive agents. J Am Med Assoc 1958, 166(2):137-140.

10. DiBona GF, Kopp UC: Neural control of renal function. Physiol Rev 1997, 77(1):75197.

11. Persu A, Maes F, Renkin J, Pathak A: Renal Denervation in Hypertensive Patients: Back to Anatomy? Hypertension 2020, 76(4):1084-1086.

12. Ram CVS: Status of Renal Denervation Therapy for Hypertension. Circulation 2019, 139(5):601-603.

13. Townsend RR, Mahfoud F, Kandzari DE, Kario K, Pocock S, Weber MA, Ewen S, Tsioufis K, Tousoulis D, Sharp ASP et al: Catheter-based renal denervation in patients with uncontrolled hypertension in the absence of antihypertensive medications (SPYRAL HTN-OFF MED): a randomised, sham-controlled, proof-of-concept trial. Lancet 2017, 390(10108):2160-2170.

14. Sakakura K, Ladich E, Cheng Q, Otsuka F, Yahagi K, Fowler DR, Kolodgie FD, Virmani $\mathrm{R}$, Joner $\mathrm{M}$ : Anatomic assessment of sympathetic peri-arterial renal nerves in man. J Am Coll Cardiol 2014, 64(7):635-643.

15. Page IH, Heuer GJ: The Effect of Renal Denervation on Patients Suffering from Nephritis. J Clin Invest 1935, 14(4):443-458.

380 16. Page IH, Heuer GJ: The Effect of Renal Denervation on the Level of Arterial Blood Pressure and Renal Function in Essential Hypertension. J Clin Invest 1935, 14(1):2730. 
17. Bhatt DL, Kandzari DE, O'Neill WW, D'Agostino R, Flack JM, Katzen BT, Leon MB, Liu M, Mauri L, Negoita $M$ et al: A controlled trial of renal denervation for resistant hypertension. N Engl J Med 2014, 370(15):1393-1401.

18. Fengler K, Ewen S, Hollriegel R, Rommel KP, Kulenthiran S, Lauder L, Cremers B, Schuler G, Linke A, Bohm M et al: Blood Pressure Response to Main Renal Artery and Combined Main Renal Artery Plus Branch Renal Denervation in Patients With Resistant Hypertension. J Am Heart Assoc 2017, 6(8).

19. Patel HC, Hayward C, Vassiliou V, Patel K, Howard JP, Di Mario C: Renal denervation for the management of resistant hypertension. Integr Blood Press Control 2015, 8:57-69.

20. Haemmerich D, Schutt DJ: RF ablation at low frequencies for targeted tumor heating: In vitro and computational modeling results. IEEE Trans Biomed Eng 2010, 58(2):404410.

21. Tungjitkusolmun S, Staelin ST, Haemmerich D, Tsai JZ, Webster JG, Lee FT, Jr., Mahvi DM, Vorperian VR: Three-Dimensional finite-element analyses for radio-frequency hepatic tumor ablation. IEEE Trans Biomed Eng 2002, 49(1):3-9.

22. Tungjitkusolmun S, Woo EJ, Cao H, Tsai JZ, Vorperian VR, Webster JG: Finite element analyses of uniform current density electrodes for radio-frequency cardiac ablation. IEEE Trans Biomed Eng 2000, 47(1):32-40.

23. Leertouwer TC, Gussenhoven EJ, van Jaarsveld BC, van Overhagen $H, B o m ~ N$, Man in 't Veld AJ: In-vitro validation, with histology, of intravascular ultrasound in renal arteries. J Hypertens 1999, 17(2):271-277. 
405

406

407

408

409

410

411

412

413

414

415

416

417

418

419

24. Rossmann C, Haemmerich D: Review of temperature dependence of thermal properties, dielectric properties, and perfusion of biological tissues at hyperthermic and ablation temperatures. Critical Reviews ${ }^{\mathrm{TM}}$ in Biomedical Engineering 2014, 42(6).

25. Zurbuchen U, Holmer C, Lehmann KS, Stein T, Roggan A, Seifarth C, Buhr HJ, Ritz JP: Determination of the temperature-dependent electric conductivity of liver tissue ex vivo and in vivo: Importance for therapy planning for the radiofrequency ablation of liver tumours. Int J Hyperthermia 2010, 26(1):26-33.

26. Berjano EJ: Theoretical modeling for radiofrequency ablation: state-of-the-art and challenges for the future. Biomed Eng Online 2006, 5(1):24.

27. Mikhail AS, Negussie AH, Graham C, Mathew M, Wood BJ, Partanen A: Evaluation of a tissue-mimicking thermochromic phantom for radiofrequency ablation. Med Phys $2016,43(7): 4304$.

28. Sata Y, Head GA, Denton K, May CN, Schlaich MP: Role of the Sympathetic Nervous System and Its Modulation in Renal Hypertension. Front Med (Lausanne) 2018, 5:82. 


\section{Figures}

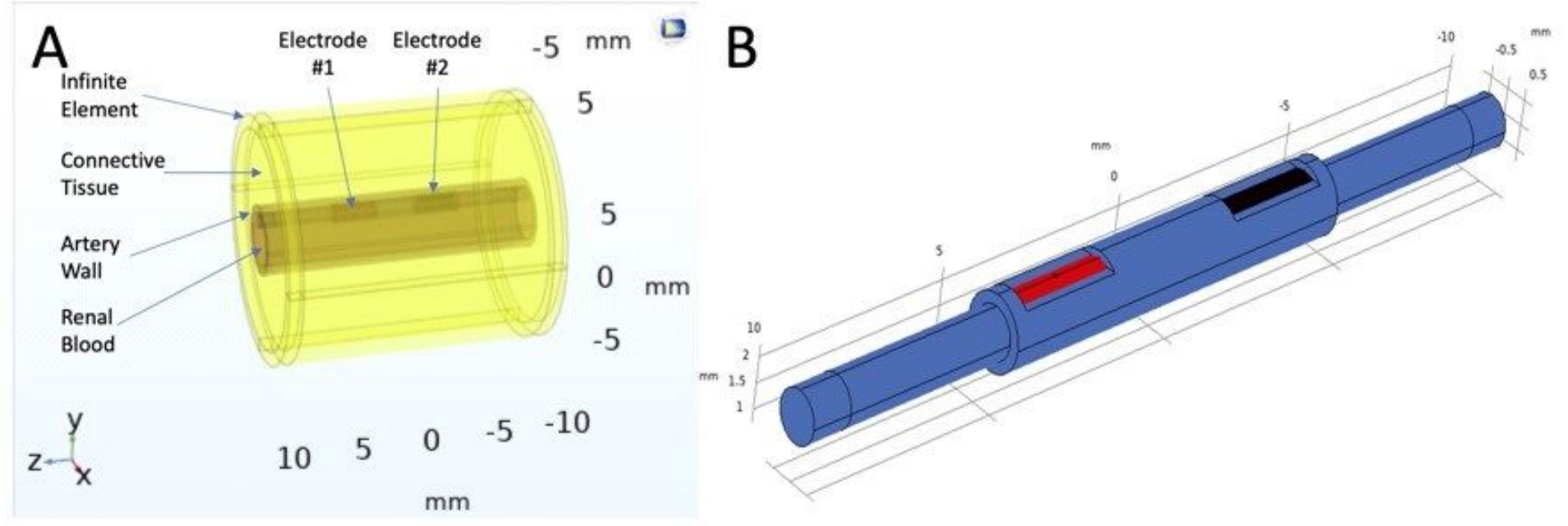

\section{Figure 1}

(A) 3D model geometry for FEM analysis of the bipolar electrodes in contact with phantom tissue to mimic placement inside the renal artery. Electrode dimensions: diameter $0.61 \mathrm{~mm}$, length $3 \mathrm{~mm}$ with a 1.5 mm separation. (B) Innovative bipolar electrode design (patent pending) to focus current density towards the artery wall and surrounding tissue. Electrodes (red and black) dimensions as per (A).

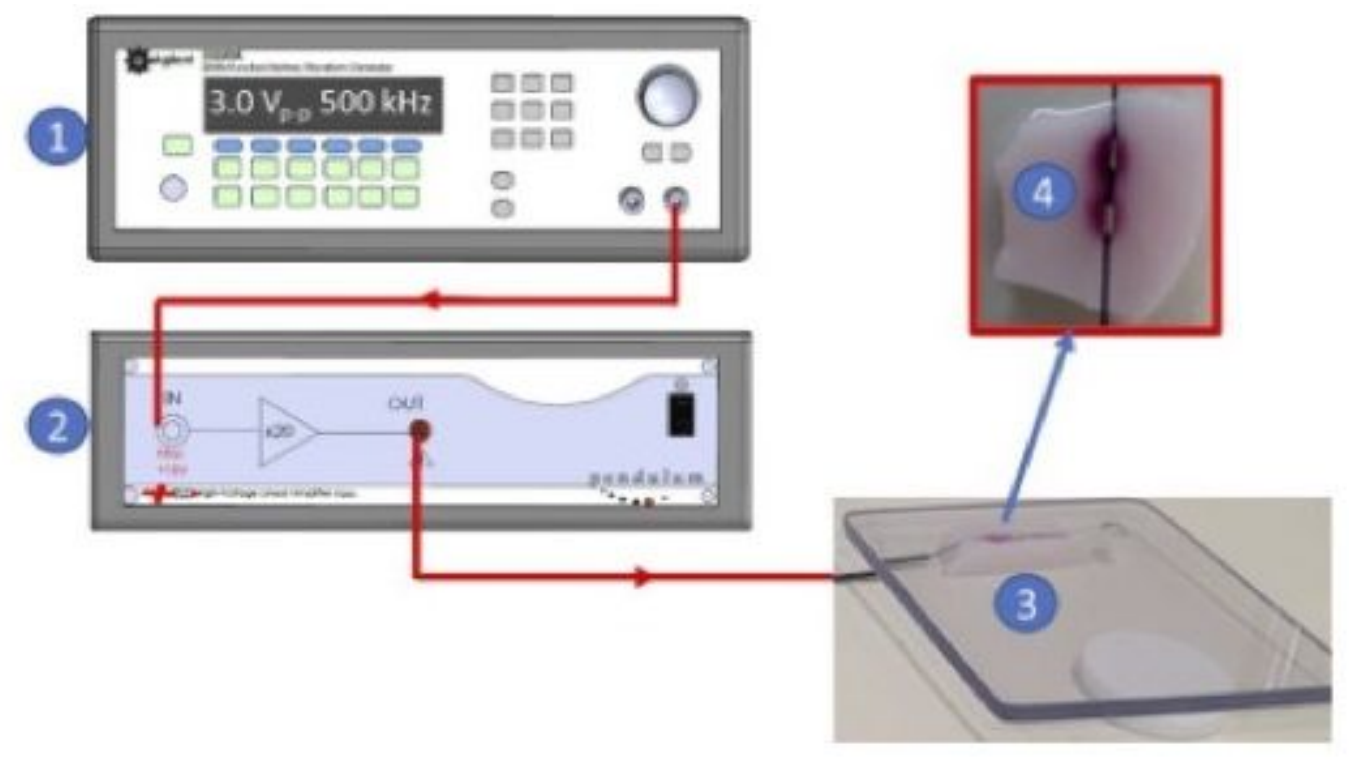

Figure 2

Thermochromic tissue phantom (TCP) ablation experimental setup. 1) Signal generator (3 Vp-p, $500 \mathrm{kHz}$ ) was amplified by 2) 20 gain linear power amplifier (60 Vp-p, $500 \mathrm{kHz}$ ) and 3) applied to TCP with a bipolar electrode and an insulating plate to maintain its position. 4) Top view of the TCP ablated by the bipolar electrodes in 60 seconds. Oscilloscope and precision meter not shown for clarity. 


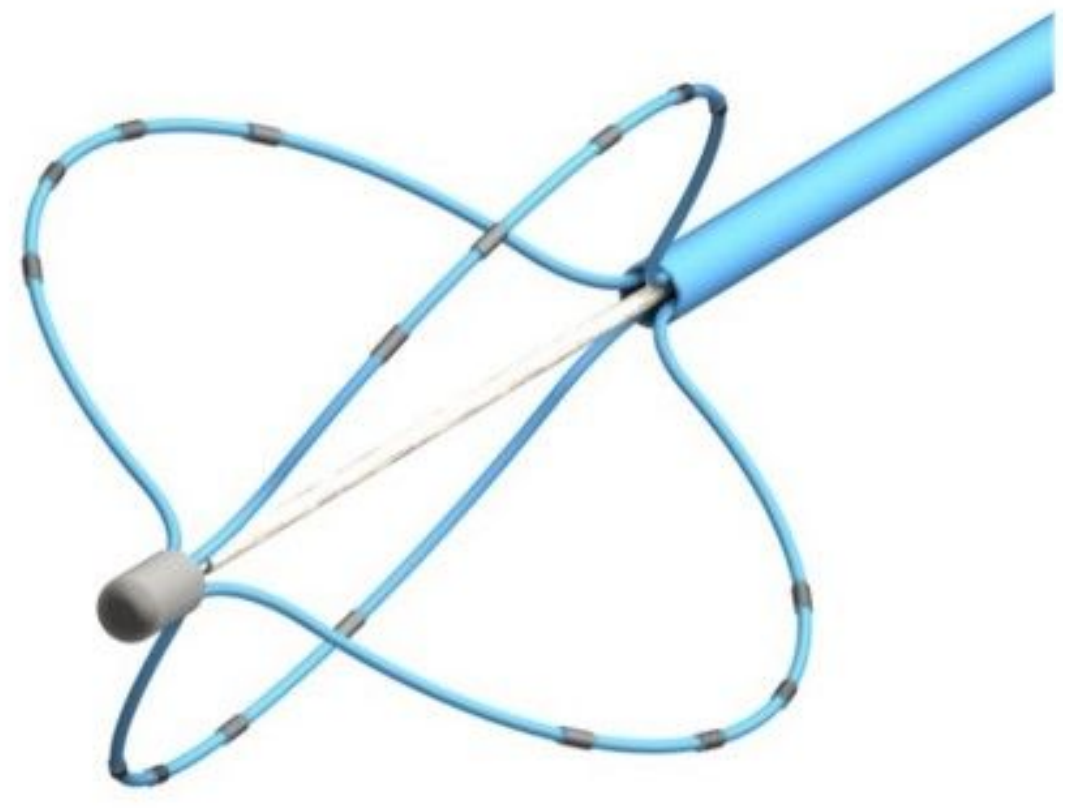

Figure 3

Graphical model of the basket catheter with four splines and four electrodes per splines. Note: two splines have a fifth, non-active radio-opaque electrode for position orientation during fluoroscopy.

A

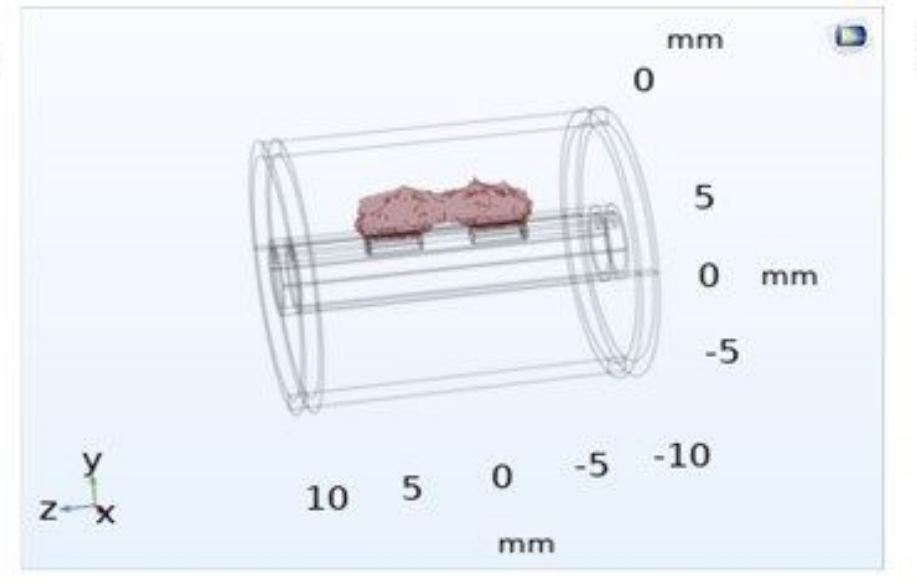

C

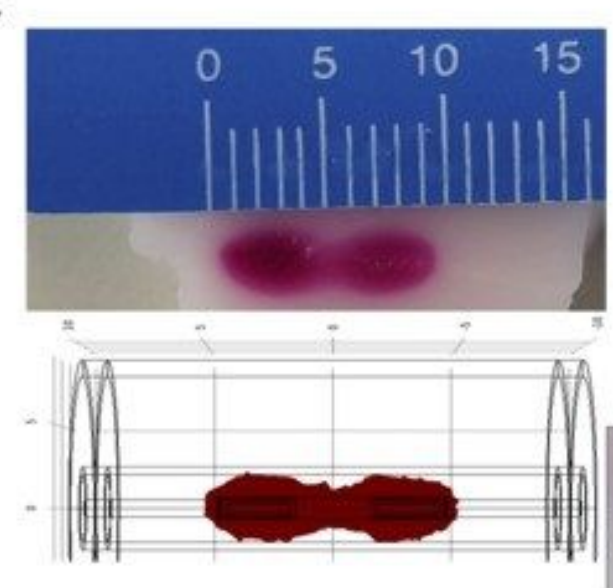

B
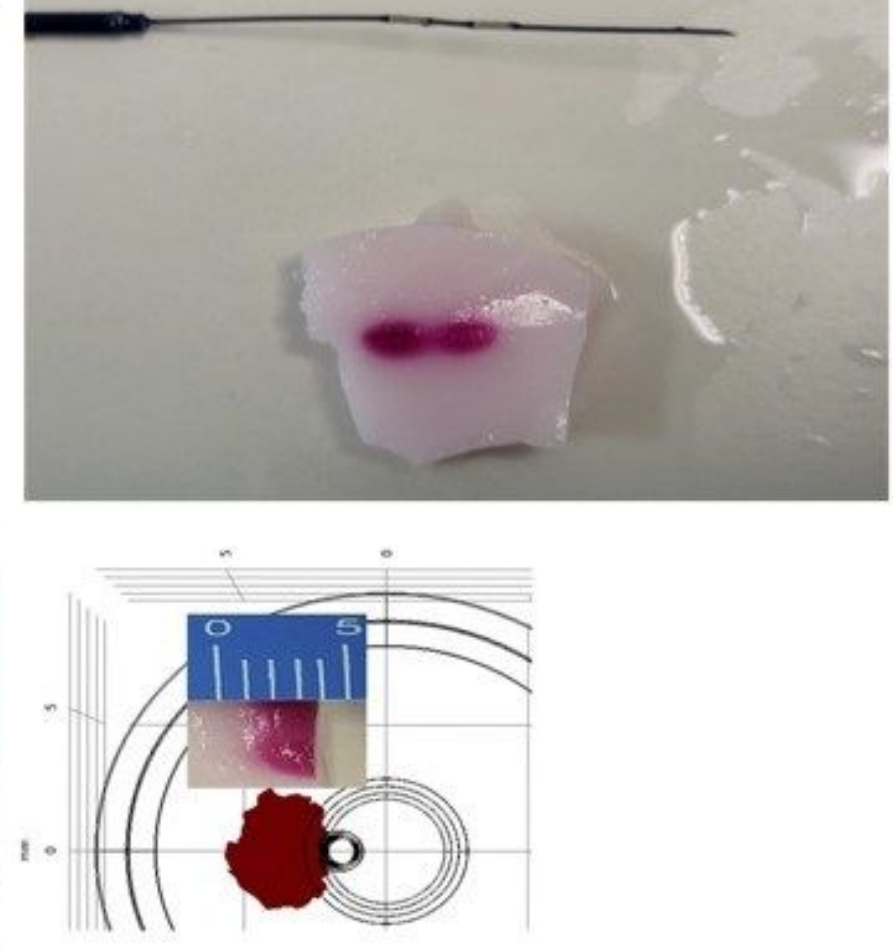

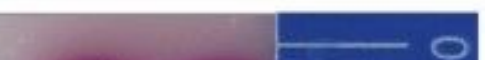




\section{Figure 4}

(A) Computer simulation of the isothermal ablation zone for a $500 \mathrm{kHz}$ input signal with an amplitude of $60 \mathrm{Vp}-\mathrm{p}$ at 60 seconds of ablation. The computer model predicted an ablation zone of $4 \mathrm{~mm} \times 10 \mathrm{~mm} \times 4$ $\mathrm{mm}$ (length $\mathrm{x}$ width $\mathrm{x}$ height) over the bipolar electrodes. (B) Thermochromic tissue phantom (TCP) after an ablation signal ( $500 \mathrm{kHz}, 60 \mathrm{Vp}-\mathrm{p})$ was applied for 60 seconds. The dark pink color change corresponds to the area where the temperature exceeded $60^{\circ} \mathrm{C}$. Note the similarities with the computer model in (A). (C) Ablation zone comparison between computer model (A) and TCP tissue experiment (B). The ablation zone was $3 \mathrm{~mm} \times 8.5 \mathrm{~mm} \times 3.5 \mathrm{~mm}$. Note the very close correlation between the experimental and simulated ablation volumes. 